\section{An Mspl RFLP detected by probe pFMS76 [D20S23] isolated from a flow-sorted chromosome 20-specific DNA library}

\author{
Frank-Michael Stolz and Ingo Hansmann \\ Institut für Humangenetik, Universität Göttingen, \\ Goßlerstraße 12d, 3400 Göttingen, FRG
}

Source/Description: pFMS76, a $4.5 \mathrm{~kb}$ HindIII fragment subcloned into the HindIII site of pBR322, was isolated from a human chromosome 20-specific gene library (Lawrence Livermore National Laboratory, California, LL20NS01, ATCC \# 57712).

Polymorphism: MspI identifies a two-allele polymorphism with bands at $9.7 \mathrm{~kb}$ (A1) and $8.2 \mathrm{~kb}$ (A2) (see figure). The DNA source is blood lymphocytes.

Frequency: A1 $(9.7 \mathrm{~kb}): 0.83$

A2 (8.2 kb): 0.17

Studied in 51 unrelated European Caucasians.

PIC $=0.24$

Not Polymorphic For: HindIII (one band at $4.5 \mathrm{~kb}$ ), PstI (two bands at 3.6 and $3.3 \mathrm{~kb}$ ), RsaI (two bands at 2.3 and $1.2 \mathrm{~kb}$ ), and TaqI (three bands at $4.3,0.9$ and $0.6 \mathrm{~kb}$ ) with panels of 5 or 6 unrelated individuals.

Chromosomal Localization: Localized to chromosome 20 using a panel of human/mouse and human/hamster somatic cell hybrids (kindly provided by Prof. K.-H.Grzeschik, Marburg, FRG).

Mendelian Inheritance: Co-dominant segregation was shown in three two-generation families (14 individuals).

Probe Availability: Available for collaboration.

Other Comments: No difficulties in standard hybridization procedures.

Acknowledgements: We thank Dr Hans Neumeyer, Abt. Transfusionsmedizin, for providing us with blood samples, Pia Ballhausen for the preparation of DNA, Dr Jochen Reiß for providing us with family DNA filters, and Andrea Scheede for the photographic reproductions. This work was supported by the Deutsche Forschungsgemeinschaft, grant Ha 747/8-1 to I.H.

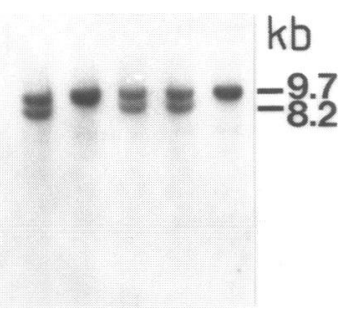

Southern blot with MspI-digested DNA from five individuals after hybridization with pFMS76.

\section{Taql polymorphism in the complement component $\mathrm{C} 7$ gene}

Eliecer Coto, E.Martinez-Naves, O.Dominguez, J.M.Urra, Victoria Rodriguez and C.LópezLarrea*

Servicio de Inmunología, Hospital Covadonga, 33006 Oviedo, Spain

Source and Description of Clone: C7-225, a 970 bp from C7-cDNA in M13 (1).

Polymorphisms: TaqI identifies two allele-RFLP with 4.2 and $4.0 \mathrm{~kb}$.

Frequency: Estimated from 30 Spanish individuals.

$4.2 \mathrm{~Kb}=0.32$

$4.0 \mathrm{~Kb}=0.68$

Not Polymorphic For: EcoRI, HindIII, BamHI and PstI.

Chromosomal Localization: The C7 gene has not yet been mapped.

Mendelian Inheritance: Codominant in four 2 generation families with 20 members.

Probe Availability: Dr Richard G.DiScipio, Scripps Clinic and Research Foundation, California, USA.

Other Comments: This polymorphism is not detected by the other probe, C7-401 $(1.7 \mathrm{~Kb})$ from C7-cDNA.

Reference: DiScipio,R.G. et al. (1988) J. Biol. Chem. 263, 549.

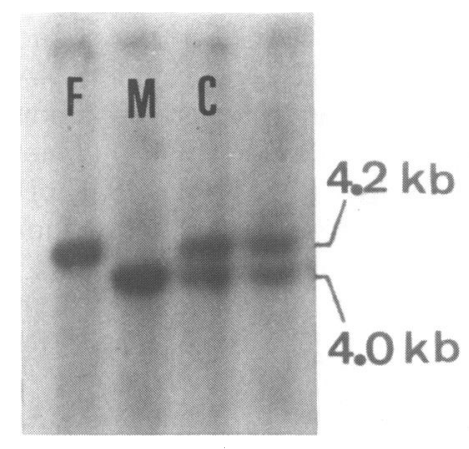

$F=$ Father.

$M=$ Mother.

$\mathrm{C}=$ Children.

* To whom correspondence should be addressed 